\title{
認知方略での動機づけと対処行動の関係性に関する研究
}

\author{
○藤原洋史 ${ }^{1} \cdot$ 岩淵千明 ${ }^{2}$ \\ ( ${ }^{1}$ 川崎医療福祉大学大学院医療福祉学研究科臨床心理学専攻 $\cdot{ }^{2}$ 川崎医療福祉大学医療福祉学部臨床心理学科) \\ キーワード：認知方略，動機づけ，対処行動
}

\section{Study on relationship between motivation and coping behavior in cognitive strategies}

Youji FUJIWARA ${ }^{1}$ and Chiaki IWABUCHI ${ }^{2}$

$\left({ }^{1}\right.$ KAWASAKI University of Medical Welfare Graduate School of Health and Welfare Master's Program in Clinical Psychology •

${ }^{2}$ KAWASAKI University of Medical Welfare Clinical Psychology, Faculty of Health and Welfare)

目 的

Key Words: cognitive strategy, motivation , coping behavior

認知方略とは，問題状況に直面した際に，人が目標や行動 に向かうための評価・計画・予測・努力などの一定の傾向と 定義されている (Norem1986)。その認知方略は期待と前歴の 高低によって分類される (表 1 参照)。これらの用いる認知方 略の違いによって, 個 人特性や動機づけ, 精 神的健康などが異な

\begin{tabular}{|c|c|c|}
\hline \multicolumn{3}{|c|}{ 表1. 認知方略の分類 } \\
\hline & 高 & 低 \\
\hline 前原 & 方略的楽観主義 & 防衛的悲観主義 \\
\hline & 非現実的楽観主義 & 真の悲観主義 \\
\hline
\end{tabular}
ることが認められて 前歴 低非現実的楽観主義 真の悲観主義 いる（e.g., 光浪, 2010 ; 細越・小玉, 2009)。

認知方略は課題場面の領域に特化したもので状況次第で変 化するとされている（Norem，2001）。また，光浪（2009）の 研究でも認知方略ごとに達成目標が異なることが認められて いる。このことから, 認知方略ごとに出来事の重要性が行動 に与える影響に違いがあると考えられる。

本研究では, 同様に悲観的である防衛的悲観主義と真の悲 観主義において, 動機づけが対処行動に与える影響が異なっ ているかを検討することを目的とする。

\section{方 法}

調查協力者 $\mathrm{A}$ 大学の大学生 255 名を対象に行った。その後, 回答に不備があったものを除いた。その結果, 246 名（男性 93 名, 女性 153 名）を分析対象者とした。

調査時期 学年末試験直前である 2014 年 1 月末に行った。 調査方法 大学の講義時間を利用して質問紙の配布を行った。 質問紙構成 フェイスシート 学年, 学科, 性別, を尋ねた。 (1)防衛的悲観主義 ; 荒木（2008）の防衛的悲観主義尺度を用 いた。因子は悲観 12 項目, 過去の成績 4 項目, 成功熟考 5 項 目，努力 3 項目について 5 件法での回答を求めた。(2)自己決 定感 ; 岡田・中谷（2006）の学習動機づけ尺度を用いた。因
子は統合的調整 12 項目, 同一化的調整 4 項目, 取り入れ的調 整 14 項目, 外的調整 3 項目について 5 件法での回答を求めた。 (3)目標志向性; 光浪 (2009) が Elliot \& Church の The Achievement Motive Scale を翻訳したものを使用した。因子は 熟達目標 8 項目, 遂行接近目標 6 項目, 遂行回避目標 3 項目 について 5 件法での回答を求めた。(4)対処行動; Takeuchi \& Greenglass（2004）の The Proactive Coping Inventory:日本語版 の下位尺度の内省的コーピング, 計画的コーピング, 予防的 コーピング，回避的コーピングの項目を試験場面に適した質 問項目に改編し, 適さない項目は除外した。因子分析をおこ ない, 場面想定, 準備, 諦めの 3 つの因子となった。

\section{結果と考察}

各尺度を探索的因子分析をして，因子得点を算出した。認 知方略を分類するために, 悲観, 成功熟考, 過去の成績, 努 力の因子を用いて, クラスタ分析によって 4 つのクラスタに 分類した。結果は荒木（2008）とほぼ同様の結果であった。 認知方略を 4 つの母集団として多母集団共分散構造分析を 行った。モデルの適合度指標は $\chi^{2}(33)=17.92, p<.98, \mathrm{GFI}=.98$ AGFI=.90, CFI=1.00, RMSEA=.00であった。防衛的悲観主義と 真の悲観主義のパスを図に示す。統合的, 同一化的調整から 熟達目標や成功達成目標への正の影響は各認知方略に認めら れた。また, 防衛的悲観主義において, 同一化的から準備一 のパスが確認された。これは, 課題の社会的価值が準備行動 を促進すると考えられる。さらに, 成功達成, 失敗回避から 準備へのパスが確認され, 課題場面の成否を気にして準備活 動をしていると考えられる。一方, 真の悲観主義において, 準備への回帰は熟達目標の負の影響のみであり, その課題に ついて興味, 関心がある場合において準備行動が促進される ことが明らかとなった。

\section{自己決定感目標志向性}

対処行動

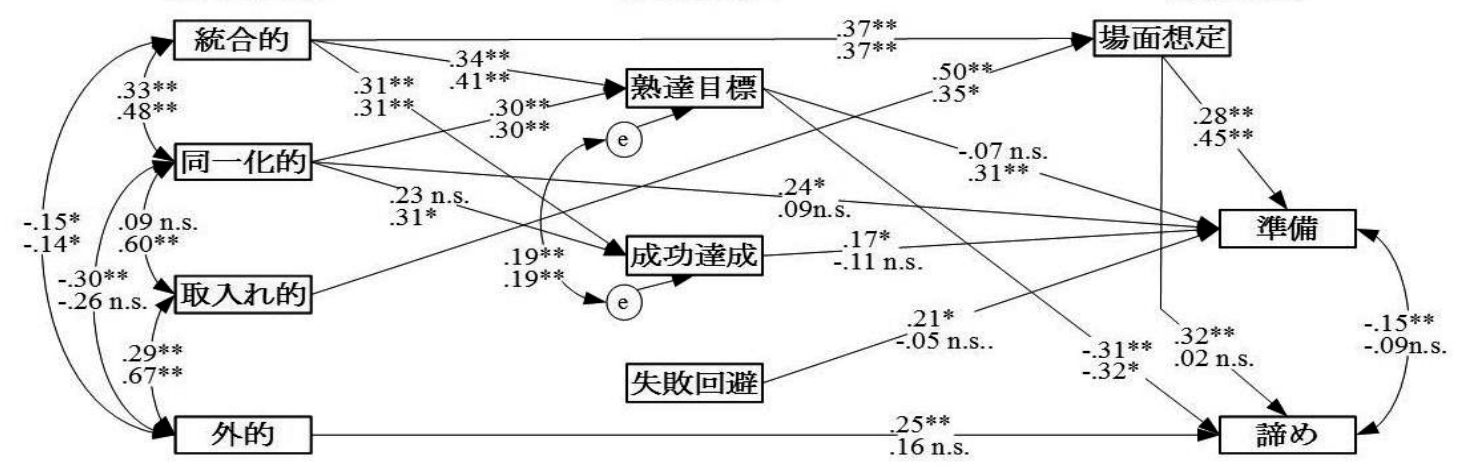

1）回帰係数は非標準化回帰係数を示している。上記が防衛的悲観主義, 下記が真の悲観主義の回帰係数である。

2）統合的から場面想定一回帰，同一化的から熟達目標へ回帰，熟達目標と成功達成の共分散は等值制約をおこなっている。

図 1 認知方略における動機づけと対処行動との関係 